\title{
The Financing of Italian Shipping Firms
}

\author{
Belinda Laura Del Gaudio ${ }^{1}$ \\ ${ }^{1}$ Department of Management Studies and Quantitative Methods, University of Naples Parthenope, Napoli, Italy \\ Correspondence: Belinda Laura Del Gaudio, Via Generale Parisi 13, Napoli, 80132, Italy.
}

Received: January 21, 2018

Accepted: March 12, 2018 Online Published: March 20, 2018

doi:10.20849/iref.v2i1.346

URL: https://doi.org/10.20849/iref.v2i1.346

\begin{abstract}
Bank financing has traditionally been the most prominent source of external finance in shipping industry. The maritime transport sector has undergone numerous changes due to both the economic growth of the emerging countries and the legislative response following the financial crisis (Basel 3). In particular, the tightening on capital adequacy has produced a banking disengagement in terms of loans to the sector that has led to changes in the financing of shipping business. The present paper examines the composition and the dynamics of the mix of alternative forms of financing of Italian shipping firms. The analysis focuses on a sample of 500 Italian companies active in the maritime transport sector between 2007 and 2015. The analysis is aimed analyse the response in the maritime sector to the trend of banks "disengagement" and compares it with the international trend. The results show that the response to bank disengagement should be better articulated since all alternative forms of financing are not widely used, in particular the stock and bond market suffer of very low volume and intensity. The benefits deriving from the diversification of the mix of alternative forms of financing should be object of further studies especially in the field of risk management.
\end{abstract}

Keywords: shipping finance, bank credit, risk management

\section{Introduction}

The maritime sector plays a major role in the global economy. In the global trade, the shipping transport represent approximately the $90 \%$ of transports, thanks to the availability of vessels, the relative low cost and the efficiency of maritime transport (ECB supervision, 2017). In the last twenty years, this sector has undergone numerous changes due to both the rapid growth in transport demand generated by the increase in production and exports from emerging countries, and the introduction of new regulations that have affected the main players in the market and in turn the banks which are the main source of shipping firm financing (Drobetz et al., 2013).

Notwithstanding, the increasing volumes and the prominent role in the economy as a whole of the shipping industry is accompanied by numerous frictions to which the shipbuilding industry is subject, as a result of the introduction of the recent regulatory provisions in the banking and accounting sectors, added to the effects of financial crisis, have created profound changes in the institutional economic environment still in progress. In particular, the introduction of the valuation at fair value, assessing market values of the company assets rather than the historical cost adopted up to a few decades ago has made evident the real capacity of the guarantees which borrower companies are able to provide. The Basel 3 regulations, has potentially made the naval credit in terms of opportunity cost "more expensive" tightening the capital constraints on banks for loans granted and requiring greater provisions. All this, added to the prolonged slowdown of the maritime industry has had a negative impact on banks' exposure to the sector. Consequently, numerous banks have left the market, reducing the volume of loans to this sector both in absolute and relative terms (Moody's, 2017). However, this form of bank disengagement has not lowered the levels of criticality so much, so that the European Central Bank (ECB) has promoted a special program among its priorities for supervision. This program is aimed at monitoring the concentration of exposures to specific asset classes which could have a significant impact in terms of capital for the banks involved, and is particularly aimed at monitoring the banks exposed to loans to maritime transport companies, including through in-depth on-site inspections at (ECB supervision, 2017).

Global bank disintermediation and the tendency of a progressive disengagement towards the maritime sector has resulted in a greater diversification of the forms of financing of companies, which have collected financial resources also through the listing on the stock exchange and the issuance of debt instruments (Albertijn et al., 2011). Furthermore, the shipping industry has attracted numerous institutional investors who have invested 
billions of dollars into the sector (Marine Money, 2017).

On these premises, the present paper present new evidence on the composition and dynamics of the mix of alternative sources of financing in the Italian context, comparing them with the global trend. The evidence shows that the disengagement of banks still requires a prompt response from Italian companies that, is still poorly articulated. In particular, it the stock market or to the private placement of debt is still low in volume and intensity. Private equity should be considered a valid alternative and/or solution only in particular situations. The benefits deriving from the diversification of the sources of financing may further mitigate the risk by favouring the already experienced risk management with hedging techniques using derivative instruments. These benefits could be the object of further investigation.

Section 2 illustrates the salient facts concerning the financing of maritime businesses at a global level. Section 3 describes data, univariate analysis and discussions. Section 4 concludes.

\section{The Financing of Shipping Firms in a Changing Context}

Maritime transport is a "capital intensive" industry that requires large amounts of financial resources for the financing of its projects. These resources are essentially drawn from third-party lenders (Agovino et al., 2014) and in particular from credit intermediaries (Mitroussi et al., 2016).

It is also a conservative sector with borrowers oriented towards traditional financing methods rather than more sophisticated and complex financial instruments (Shipping Finance, 2013). Capital intensity, high volatility in freight rates, cyclicality and seasonality, strongly linked to the economic cycle and direct exposure to the fluctuations of the local and global economy create a risky investment environment for banks (Drobetz et al., 2013). In addition, maritime companies are faced with substantial business risks resulting from the large queues of freight rate distributions, travel and operating costs. This leads to extremely uncertain cash flow and profoundly affects the company's ability to generate income and repay the debt (Kavussanos \& Visvikis, 2006; $\mathrm{Xu}$ et al., 2011).

According to ABN AMRO estimates (2011), more than $80 \%$ of the external financing of the shipping companies consists of debt, of which $75 \%$ comes from banks and the remaining $5 \%$ from the bond and equity market (Albertijn et al., 2011). The number of banks active in the shipping industry has significantly decreased over the years, and has drastically decreased following the 2007 financial crisis (Shipping Finance, 2013). To date, the players remaining on the market dedicate their activity to the restructuring of the old debt rather than to new loans (Moodys, 2017). In general, new loans have common evidence: they are fully guaranteed, volumes are lower and have a shorter duration compared to the pre-crisis period (Albertijn et al., 2011). The macroeconomic situation, in concurrence with the introduction of the banking legislation, Basel 3, concerning the capital adequacy and liquidity requirements; as well as the accounting standards to which the major shipping companies are subjected to the valuation and expression in the financial statements of the values of the assets at fair value; created a mix of unfavourable conditions for the financing of shipping firms. From the bank point of view, ship loans should become less profitable for the lender for three reasons. Firstly, the adoption of the international accounting standards and in particular the expectation of expressing assets at fair value bring out the high volatility of the price of the vessels and consequently the real capacity of the collateral (collateralizable assets to the loan) it is more easily to evaluate. Secondly, the Basel 3 framework, which includes new capital adequacy constraints, requires the bank to allocate more capital to the same pre- and post-crisis naval loan, with a corresponding increase in the opportunity cost of the operation. Finally, many companies with only one vessel have insufficient guarantees to offer for loans granted to them by banks, as emerged from the recent financial crisis. However, only in the last few decades the major owners have chosen global capital markets (Grammenos et al., 2007; Merikas et al., 2009). While for small businesses the market alternative almost precluded the bank loans are the main source of debt financing, in addition to the capital funds in the maritime industry deriving from informal loans (financing members and intra-group loans) and self-financing.

On the other hand, the financial crisis made also difficult to resort to the stock and bond market for the reasons outlined above. Moreover, the overcapacity of ships exacerbated by the slowdown in global economy has led to a decrease in demand of goods reducing in turn the demand for transport. Many of the fleets that have commissioned new ships remain unused, thus exacerbating the companies' budgets. Shipping companies with freight ships have also suffered a sharp drop in transport rates in recent years as many of their rental rates have been set at high rates during the times of the previous boom. This mix of negative trends has compressed profitability and negative results are evident in the capital markets as many listed shipping companies continue to trade below the net asset value (Fitch Ratings, 2013). 


\section{Descriptive Analysis: Sampling and Results}

The sample contains 500 Italian shipping companies balance sheet data for the period between 2007 and 2015. In the dataset included only the sector linked to the maritime transport of goods and passengers, setting aside the shipbuilding sector. The dataset was built from the information available on Aida database Bureau Van Dijk, skimming by type of activity with code ATECO 2007 H 50 (maritime transport) with an additional filter excluding maritime transport for inland waters (the use of this filter in any case did not change the search results). 824 companies in the maritime transport sector in Italy, are excluded 131 of which are in a state of liquidation, as the present study considers the financing decisions of performing assets. Companies that did not have any financial data (158 companies) and companies that were in a state of receivership, although still active (35 companies), have been further eliminated. The dataset is made up of 500 companies active at 06/19/2017 in the marine transport sector H50-502 for which there are balance sheet data for the period between 2007 and 2015.

Table 1 reports selected variables of balance sheet information of Italian shipping companies and their main statistics. The maritime transport sector is considerably fragmented, with a relatively high number of small and medium businesses. Considering revenues as a dimensional variable, $75 \%$ of companies are very small as they have average revenues of 4.009.00 and this data is so far from the maximum value of revenues 1,456,134.00. The high variability among the classes of revenue, streams suggests that the sector is composed of relatively few large top players. High variability is also present in the operating result of maritime companies, in particular, $25 \%$ of them have negative results (Table 1).

Table 1. Main balance sheet items and company information of Italian maritime transport companies from 2007 to 2015 (thousands of euros)

\begin{tabular}{lcccccccc}
\hline & & & & & \multicolumn{2}{c}{ Percentiles } & & \\
Variables & $\mathrm{N}$ & Mean & $\mathrm{Sd}$ & Median & $25^{\circ}$ & $75^{\circ}$ & Min & Max \\
\hline Sales & 3463 & $16,367.74$ & $83,821.70$ & 778.00 & 153.00 & $4,009.00$ & 0.00 & $1,456,134.00$ \\
Free cash flow operative & 3467 & $2,147.22$ & $13,417.94$ & 40.00 & 2.00 & 290.00 & $-198,122.00$ & $291,826.00$ \\
Net working capital & 3471 & $-1,321.14$ & $25,565.21$ & 5.00 & -172.00 & 183.00 & $-379,135.00$ & $313,166.00$ \\
Operational Results & 3467 & 708.33 & $10,633.16$ & 17.00 & -9.00 & 131.00 & $-228,148.00$ & $216,350.00$ \\
\hline
\end{tabular}

Source: own elaboration.

Figure 1 shows the dynamics of liquidity. On average, the ability to generate liquidity for companies in the sample is almost stable until 2012, starting from that year there a slight fall is followed by a rapid recovery in operating cash flow. The trend of average net working capital shows an improvement in the financial structure of the companies present in the sample over the years. In fact, the negative values that have distinguished the margin of liquidity examined in the first years of the analysis, indicate in the first instance a loan of fixed assets through short-term sources, and a possible financial imbalance. These values gradually increased until they changed sign, thus becoming positive in 2015 (Figure 1). 


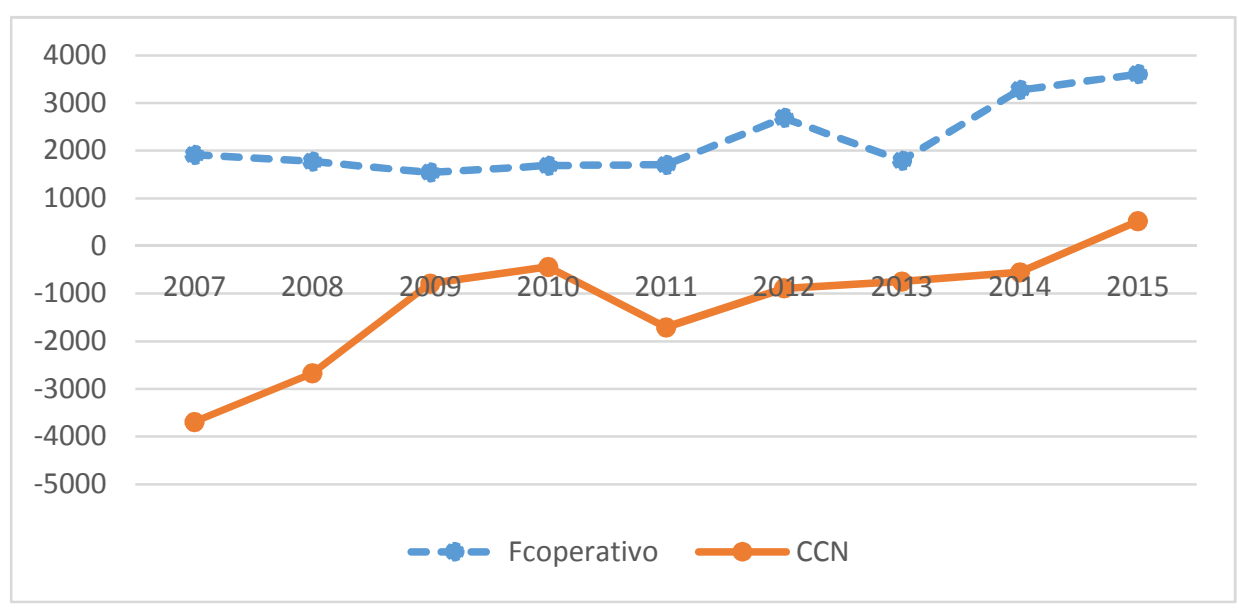

Figure 1. Dynamics of operative free cash flow and net working capital

Source: own elaboration.

Table 2 depicts the ownership concentration of Italian shipping firms. Italian operators in the maritime transport of goods still have a markedly "family" characterization regard to their ownership structures. The prevalence of consolidated groups founded by families of traditional ship-owners is well known (Agovino et al., 2014). In the sample, a limited number of companies has centralised management. Especially, 25\% of the sample consists of companies in which there is no separation between ownership and control, and the figure of the manager and owner coincide. These companies are small in size and present strong critical elements in the balance sheet data revealing a non-profitable economic situation. In recent years the positive trend of Italian ship-owners has been increasingly strong, in addition to diversifying its fleets in the various transport sectors (in order to compensate for any different trend in the relative market cycles), to expand its area of operations in sub-sectors related to maritime transport, with a process of gradual differentiation of the business through the establishment/acquisition of logistics companies or the definition of partnerships. In a group there are about 9 companies with an average of shareholders and managers equal to 3 and 4 respectively. The shareholding is thus defined by a narrow base of risk capital participants and the figure of manager/shareholder coincides in $25 \%$ of the cases (Table 2).

Table 2. Ownership and board characteristics

\begin{tabular}{|c|c|c|c|c|c|c|c|c|}
\hline \multirow[b]{2}{*}{ Variables } & \multirow[b]{2}{*}{$\mathrm{N}$} & \multirow[b]{2}{*}{ Mean } & \multirow[b]{2}{*}{$\mathrm{Sd}$} & \multirow[b]{2}{*}{ Median } & \multicolumn{2}{|c|}{ Percentiles } & \multirow[b]{2}{*}{ Min } & \multirow[b]{2}{*}{ Max } \\
\hline & & & & & $25^{\circ}$ & $75^{\circ}$ & & \\
\hline $\mathrm{n}^{\circ}$ companies group & 4500 & 8.74 & 36.91 & 2.00 & 0.00 & 4.00 & 0.00 & 386.00 \\
\hline $\mathrm{n}^{\circ}$ manager & 4500 & 4.36 & 5.74 & 3.00 & 1.00 & 5.00 & 0.00 & 62.00 \\
\hline $\mathrm{n}^{\circ}$ shareholder & 4500 & 3.20 & 6.71 & 2.00 & 1.00 & 3.00 & 0.00 & 113.00 \\
\hline
\end{tabular}

Source: own elaboration.

Figure 2 represents the dynamics of selected profitability ratios. The profitability of maritime transport companies is analysed through three main indicators: the return on assets (ROA); return on equity (ROE) and return on sales (ROS). These indices report operating income to the value of total assets and revenues (respectively in the case of ROA and ROS), and of net income to capital (in the case of ROE). The profitability of shipping companies declined sharply until 2012 for all three indices examined. The trend has even turned negative for the return on assets (ROA), while it has resumed growth in return on capital (ROE) and sales (ROS) since 2013 (Figure 2). 


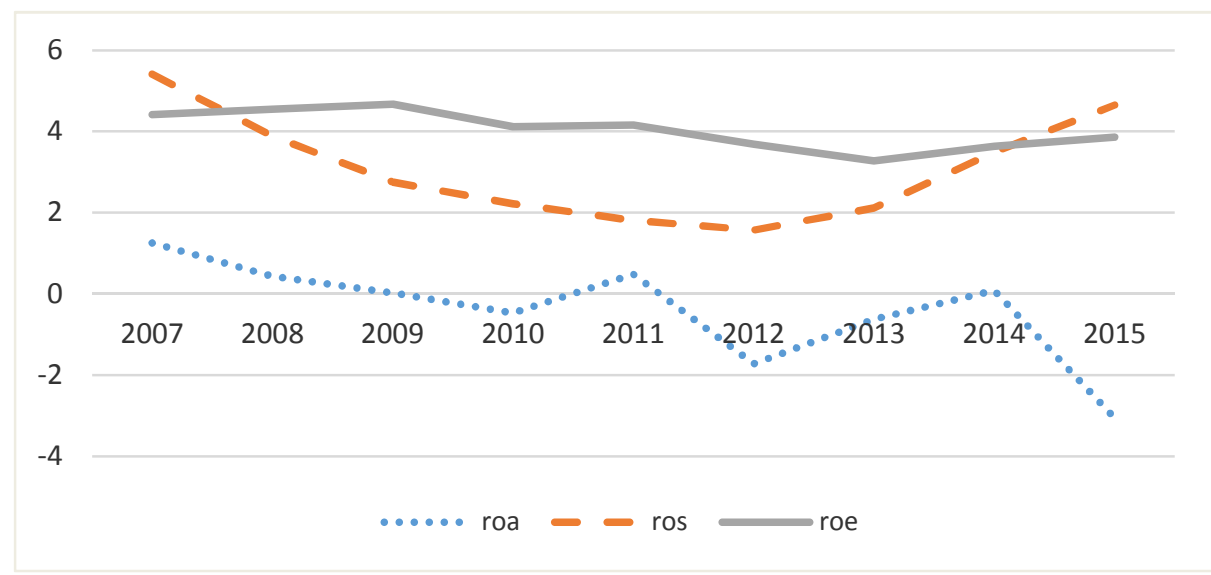

Figure 2. Dynamics of profitability ratios

Source: own elaboration.

Table 3 contains all items of selected variables. In addition to the profitability ratios are also reported information on the capital structure. In the sample, $25 \%$ of the companies considered were affected by negative profit margins. The average leverage, defined by the sum of short and long-term payables on total assets, of the Italian sector is equal to 0.7 , while the so-called tangibility, expressed as the ratio between tangible assets and total assets, and represents the possible value that can be pledged (firm collateralizable value), is equal to 0.43 . The study of Italian data reveals a high hetereogeneity of the value of assets collateralizable. In particular, the variation between the values of the tangibility ratio of the companies of the 25th percentile $(0.08)$ and the median $(0.43)$ is high. This means that many companies with operate same leverage but have less guarantees to offer to creditors. Bank loans are the most widely used form of financing by shipping companies, both in short and medium-long term. Further, evidence that is confirmed in the Italian context is the use of commercial credit. In fact, the median company has similar volumes of commercial credit and short-term bank financing. The value of suppliers (payables to suppliers within the year) and banks_within (payables to banks within the financial year) is equal to $1,399.00$ and $1,475.50$ respectively (Table 3 ).

Table 3. Indici di redditività e struttura finanziaria delle imprese del trasporto marittimo italiane nel periodo 2007-2015 (dati in migliaia di euro)

\begin{tabular}{|c|c|c|c|c|c|c|c|c|}
\hline \multirow[b]{2}{*}{ Variables } & \multirow[b]{2}{*}{$\mathrm{N}$} & \multirow[b]{2}{*}{ Mean } & \multirow[b]{2}{*}{$\mathrm{Sd}$} & \multirow[b]{2}{*}{ Median } & \multicolumn{2}{|c|}{ Percentiles } & \multirow[b]{2}{*}{ Min } & \multirow[b]{2}{*}{ Max } \\
\hline & & & & & $25^{\circ}$ & $75^{\circ}$ & & \\
\hline Ros & 2854 & 3.03 & 12.80 & 3.63 & -0.40 & 9.92 & -49.95 & 29.84 \\
\hline Roa & 3463 & -0.50 & 40.03 & 2.34 & -1.70 & 7.51 & -872.84 & 92.65 \\
\hline Roe & 3089 & 3.86 & 33.50 & 3.25 & -4.57 & 16.63 & -146.77 & 132.12 \\
\hline Debttoequity & 3068 & 3.67 & 30.15 & 0.28 & 0.00 & 1.57 & -135.51 & 996.09 \\
\hline Leverage & 3471 & 0.70 & 2.21 & 0.66 & 0.41 & 0.85 & -0.04 & 120.85 \\
\hline Tangibility & 3463 & 0.43 & 0.33 & 0.43 & 0.08 & 0.74 & 0.00 & 1.00 \\
\hline Bonds & 1087 & $2,383.86$ & $26,927.80$ & 0.00 & 0.00 & 0.00 & 0.00 & $398,336.00$ \\
\hline Shareholder financing & 1087 & 313.86 & $1,970.88$ & 0.00 & 0.00 & 0.00 & 0.00 & $22,670.00$ \\
\hline Bank_within & 1008 & $12,450.88$ & $36,510.91$ & $1,475.50$ & 1.00 & $7,187.00$ & 0.00 & $420,402.00$ \\
\hline Bank_beyond & 1087 & $31,056.11$ & $69,018.60$ & $1,095.00$ & 0.00 & $27,287.00$ & 0.00 & $501,230.00$ \\
\hline Other lenders & 1087 & 473.44 & $3,621.38$ & 0.00 & 0.00 & 0.00 & 0.00 & $71,935.00$ \\
\hline Payables & 1008 & $6,543.29$ & $18,014.23$ & $1,399.00$ & 249.50 & $5,504.50$ & 0.00 & $185,496.00$ \\
\hline Receivables & 1013 & $6,403.50$ & $18,105.25$ & $1,032.59$ & 172.64 & $4,406.70$ & -78.07 & $254,408.50$ \\
\hline
\end{tabular}

Source:own elaboration. 
Other forms of financing such as an informal loan (shareholder loan) and the use of bonds are not widely spread. The stock market is more unique than rare case. Only two shipping companies have been listed but are currently de-listed. Private equity investments in the maritime transport sector are also quite small. On average is signed a deal per year. Every deals has it owns characteristics including special conditions. Therefore, the transactions range from restructuring and to acquisitions of equity stake or to the expansion with acquisitions of majority shareholdings (Annual Report, Private Equity Monitor).

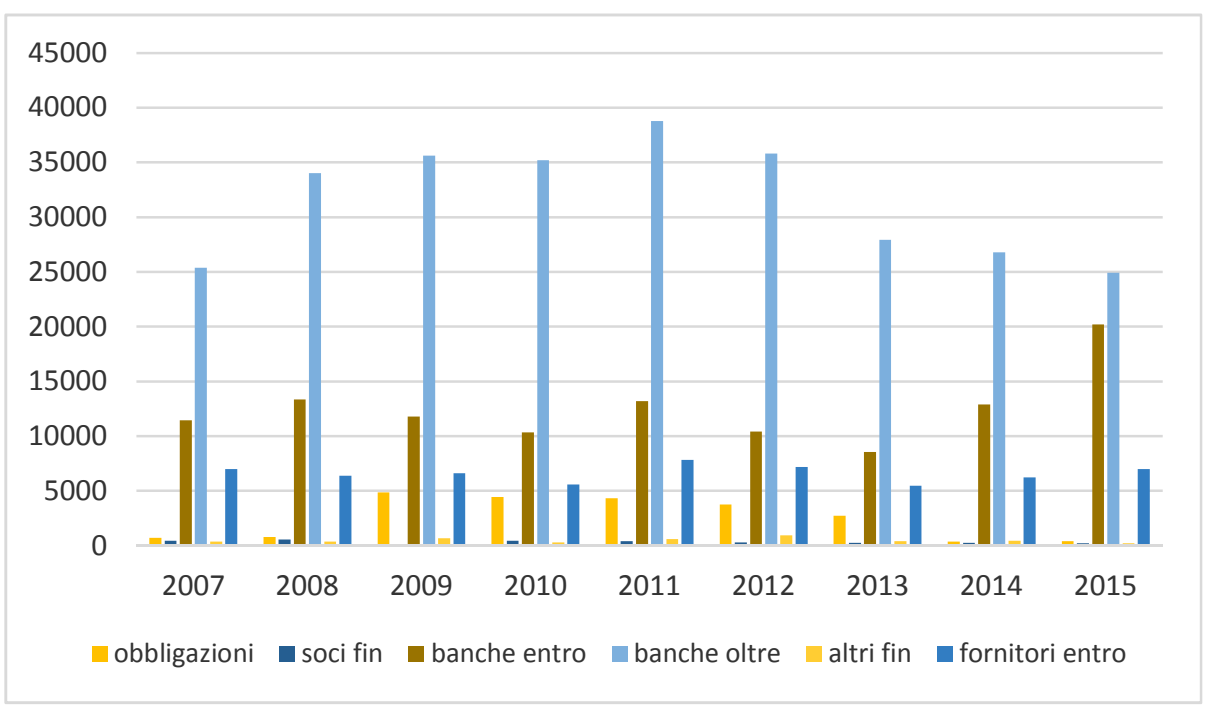

Figure 3. Mix composition and dynamics of alternative form of financing of Italian shipping companies

Source: own elaboration.

Figure 3 illustrates the mix and the composition in dynamics of the alternative source of funding examined above. The mix and the composition of funding sources on average remain almost stable. In details, bank financing is confirmed as the main form of financing used both in the form of loans and short-term loans. This finding is consistent with international results (Drobetz et al., 2013; Albertijn et al., 2011). Commercial credit follows directly, in terms of volumes, as the supplier's loan. These results are in line with several studies supporting the idea of a primary role of trade credit in firm financing (e.g., Rajan \& Zingales, 1995; Demirguc-Kunt \& Maksimovic, 2001; Omiccioli, 2002). Bond issues and informal loans play a residuals role. The trend of single items confirms the global structural changes. First, the bank disengagement starts to play after 2011, probably due also to the Italian debt sovereign crisis. As a result, shipping firms have less exposure, in the long term and on average, to bank credit. This is also the result of international changes: the introduction of the new Basel 3 regulations and the international accounting standards as previous explained.

\section{Conclusions}

Italian shipping firms strongly rely on bank credit and the alternative forms of financing are still not so much used. Bank credit disengagement start to plays since 2011 and produce low exposure of bank debt in balance sheets of shipping finance. In the total composition of sources of financing, bank credit is still very high. The bond issuance plays a residual role in shipping firm financing and the equity offer on the stock exchange is more unique case than rare, as well as private equity financing. The international trend of bank disengagement towards the shipping industry is confirmed unlike the prompt reaction of firms to challenges posed by business cycle and financial crisis and its aftermath. Findings suggest that the answer of Italian shipping firms is not much articulated as the diversification of alternative forms of financing has still not been in place.

The advantages of greater diversification of sources of financial resources alternative to the banking channel should be also appreciated in terms of risk management as well as in terms of core business. In addition, the benefits should also affect the operations already in place aimed at mitigating the risk inherent the sector activities, especially, through derivative instruments to hedge operational risk and assets. Mitigation of the risk deriving from diversification and lower reliance on bank credit could be the object of further studies. 


\section{References}

ABN AMRO. (2011). Shipping Finance and Investment: current trend in ship finance, Istanbul. 3rd Mare Forum in ship Finance.

Agovino G. V., Biancucci E., Del Sorbo V. G., \& Laudati A. (2015). Strumenti e fonti di finanziamento per le società armatoriali. Private Finance srm-maritimeeconomy.com.

Albertijn S., Bessler W., \& Drobez W. (2011, Fall). Financing shipping companies and shipping operations: a risk management perspective. Journal of Applied Corporate Finance, 23(4), $70-82$. https://doi.org/10.1111/j.1745-6622.2011.00353.x

Demirgüç-Kunt, A., \& Maksimovic, V. (2001). Firms as financial intermediaries: evidence from trade credit data (Policy Research Working Paper No. 2696). Washington, DC: The World Bank.

ECB. (2017). ECB Banking Supervision reviews lending to troubled shipping sector. Retrieved from https://www.bankingsupervision.europa.eu/press/publications/newsletter/2017/html/ssm.nl170517_1.en.htm 1

Fitch Ratings. (2013, April 25). Banks' Shipping Portfolios Still Under Pressure. Retrieved from http://www.fitchratings.com/gws/en/fitchwire/fitchwirearticle/Banks-Shipping-Portfolios?pr_id=789542

Grammenos, Costas Th, Amir H. Alizadeh, \& Nikos C. Papapostolou. (2007). Factors affecting the dynamics of yield premia on shipping seasoned high yield bonds. Transportation Research Part E: Logistics and Transportation Review, 43(5), 549-564. https://doi.org/10.1016/j.tre.2006.07.002

Grammenos, Nomikos, \& Papapostolou. (2008). Estimating the probability of default for shipping high yield bond issues. Transportation Research Part E, 44, 1123-1138. https://doi.org/10.1016/j.tre.2007.10.005

Kavussanos, M. G., Visvikis, I. D. (2006). Shipping freight derivatives: a survey of recent evidence. Maritime Policy Manag, 33(3), 233-255. https://doi.org/10.1080/03088830600783152

Marine Money. (2017). Retrieved from https://www.marinemoneyoffshore.com/node/4465

Merikas, A., Gounopoulos, D., \& Nounis, C. (2009). Global shipping IPOs performance. Maritime Policy and Management, 36 (6), 481-505. https://doi.org/10.1080/03088830903346053

Mitroussi, K., Xu, J., Petttit, S., \& Tigka, N. (2012, September). Performance drivers of shipping loans: An empirical investigation. Conference Proceedings, International Association of Maritime Economists Annual Conference, 5-8. Taipei.

Moody's. (2017). Banking - German Ship Lenders: Further Losses Ahead as Problem Loans Continue to Mount. Retrieved from http://www.moodys.com/researchdocumentcontentpage.aspx?docid=PBC_1074842

Rajan, R. G., Zingales, L. (1995). What do we know about capital structure? Some evidence from international data. Journal of Finance, 50, 1421-1460. https://doi.org/10.1111/j.1540-6261.1995.tb05184.x

Rapporto annuale Private Equity Monitor. (2007, 2008, 2009, 2010, 2011, \& 2012).

Xu, J. J., Yip, T. L., \& Marlow, P. B. (2011). The dynamics between freight olatility and fleet size growth in dry bulk shipping markets. Transp.Res.PartE, 47(6), 983-991. https://doi.org/10.1016/j.tre.2011.05.008

\section{Copyrights}

Copyright for this article is retained by the author(s), with first publication rights granted to the journal.

This is an open-access article distributed under the terms and conditions of the Creative Commons Attribution license (http://creativecommons.org/licenses/by/4.0/). 